\title{
Nocistatin inhibits pregnant rat uterine contractions in vitro: Roles of calcitonin gene-related peptide and calcium-dependent potassium channel
}

\author{
Beáta H. Deák ${ }^{a}$, Anna Klukovits a ${ }^{\text {, Kornélia Tekes }}{ }^{\text {b }}$, Eszter Ducza ${ }^{a}$, \\ George Falkay ${ }^{a}$, Róbert Gáspár ${ }^{\mathrm{a}, *}$ \\ a Department of Pharmacodynamics and Biopharmacy, University of Szeged, H-6720 Szeged, Eötvös u. 6, Hungary \\ b Department of Pharmacodynamics, Semmelweis University, H-1089 Budapest, Nagyvárad tér 4, Hungary
}

\section{A R T I C L E I N F O}

\section{Article history:}

Received 31 October 2012

Received in revised form

16 May 2013

Accepted 30 May 2013

Available online 19 June 2013

Keywords:

Uterine contractility

Nocistatin

Calcitonin gene-related peptide

Potassium channel

Pregnant rat

\begin{abstract}
A B S T R A C T
The endogenous neuropeptide nociceptin/orphanin FQ translated from the prepronociceptin gene, exerts a contraction-inhibitory effect on the rat uterus. As nocistatin has been reported to cause functional antagonism of the pro-nociceptive effects of nociceptin, we set out to investigate its effects on the pregnant rat uterus and to elucidate its signalling pathway. The expression of prepronociceptin mRNA in the uterus and nocistatin levels in the uterus and the plasma were confirmed by RT-PCR and radioimmunoassay. The uterine levels of prepronociceptin mRNA and nocistatin were significantly increased by the last day of pregnancy, while the plasma nocistatin levels remained unchanged. In the isolated organ bath studies nocistatin inhibited the prostaglandin- and the $\mathrm{KCl}$-evoked contractions in the uterus dose-dependently. This latter effect was decreased by preincubation with capsaicin. Incubation with calcitonin gene-related peptide after capsaicin treatment caused an elevation in the contraction-inhibitory effect of nocistatin. The effect of nocistatin was also decreased by the $\mathrm{Ca}^{2}$ ${ }^{+}$-dependent $\mathrm{K}^{+}$channel inhibitor paxilline, against spontaneous uterine contractions. Nociceptin potentiated the action of nocistatin. Naloxone decreased the effect of nocistatin administered either alone or in combination with nociceptin. In $\mathrm{Ca}^{2+}$-poor environment, this effect of naloxone was suspended. Enzyme immunoassay for the uterine intracellular cAMP levels partially confirmed the results of in vitro contractility studies. We conclude that nocistatin, generated locally in the uterus, exerts an inhibitory effect, the mechanism being mediated in part by $\mathrm{Ca}^{2+}$-dependent $\mathrm{K}^{+}$channels, the elevation of cAMP levels and sensory neuropeptides.
\end{abstract}

(c) 2013 Elsevier B.V. All rights reserved.

\section{Introduction}

After the identification of the endogenous ligand nociceptin (N/OFQ) of the nociceptin receptor (NOP receptor), another neuropeptide originating from the same precursor protein prepronociceptin (PNOC) was isolated (Okuda-Ashitaka et al., 1998). It was named nocistatin, with reference to its first effects described in the central nervous system, as a functional antagonist of N/OFQ (Zeilhofer et al., 2000). It has been demonstrated that nocistatin binds to a binding site that is distinct from the NOP receptor (Okuda-Ashitaka and Ito, 2000; Johnson and Connor, 2007). Nocistatin inhibits 5-hydroxytryptamine release via a $\mathrm{G}_{\mathrm{i} / \mathrm{o}}$ proteinmediated pathway (Johnson and Connor, 2007; Fantin et al., 2007).

The mRNA for PNOC is widely expressed in the brain (Neal et al., 1999; Martin et al., 1998) and in the spinal cord (Mollereau

\footnotetext{
* Corresponding author. Tel./fax: 3662545567.

E-mail address: gaspar@pharm.u-szeged.hu (R. Gáspár).
}

et al., 1996). Nocistatin attenuates the allodynia and hyperalgesia caused by the intrathecal administration of N/OFQ and $\mathrm{PGE}_{2}$ (Minami et al., 1994a, 1994b; Taiwo and Levine, 1988; OkudaAshitaka et al., 1998). Both N/OFQ and nocistatin have impacts on memory and learning (Hiramatsu and Inoue, 1999). Nocistatin suppresses appetite (Olszewski et al., 2000) and induces gastric mucosal protection (Zádori et al., 2008).

Endogenous opioid peptides are involved in the induction of the GnRH surge (Foradori et al., 2007). N/OFQ is present in several pathological conditions, such as the female fibromyalgia syndrome (Anderberg et al., 1998) and postpartum depression ( $\mathrm{Gu}$ et al., 2003), and it is a paracrine mediator of the FSH effects in the regulation of spermatogenesis (Eto et al., 2012). A high expression of N/OFQ in adenomyosis may be one of the casual factors of dysmenorrhoea (Hou et al., 2011). N/OFQ regulates the LH surge and ovarian function (Sinchak et al., 2006). The N/OFQ-NOP receptor system modulates and coordinates reproductive behaviour and physiology through actions in the limbic system and hypothalamus (Sinchak et al., 2006). 
A number of endogenous peptides participate in the regulation of uterine contractility, including oxytocin and tachykinin promoting contractions (Popescu et al., 1985; Pennefather et al., 2004; Moodley et al., 1999; Collins et al., 2002). Other neuropeptides, such as calcitonin gene-related peptide (CGRP), contribute to relaxation of the uterus smooth muscle (Shew et al., 1991; Pennefather et al., 1990; Klukovits et al., 2004). CGRP and tachykinin are localised in the capsaicin-sensitive sensory nerve endings. As labour and delivery are extremely painful, we decided to evaluate the effects of PNOC-derived peptides which have a role in pain modulation, in order to establish whether they additionally influence uterine contractility. We earlier reported that the endogenous peptide N/OFQ inhibits uterine contraction in the pregnant rat (Klukovits et al., 2010).

Our present aims were to detect the expression of PNOC mRNA and nocistatin in the late-pregnant rat uterus and to clarify the effects of nocistatin alone or in combination with N/OFQ in vitro. We hypothesised that $\mathrm{Ca}^{2+}$-activated $\mathrm{K}^{+}$channels $\left(\mathrm{K}_{\mathrm{Ca}} 1.1\right)$ and outward $\mathrm{K}^{+}$currents, the changes in intracellular cAMP levels, and sensory neuropeptide CGRP may be involved in the uterine effects of nocistatin. Additionally, we aimed to investigate the opiatereceptor-independent peripheral actions of nocistatin.

\section{Materials and methods}

\subsection{Animals}

The animals were treated in accordance with the European Communities Council Directives (86/609/ECC) and the Hungarian Act for the Protection of Animals in Research (XXVIII.tv.32.§). All experiments involving animal subjects were carried out with the approval of the Hungarian Ethical Committee for Animal Research (registration number: IV./01758-2/2008) and under the control of the ISO-9001:2008 Quality Management System.

Sexually mature female Sprague-Dawley rats (body mass: 160 $200 \mathrm{~g}, 50-60$ days old) were mated in the early morning hours. Copulation was confirmed by the presence of a copulation plug or spermatozoa in the vagina. The day of copulation was considered to be the first day of pregnancy. The animals were housed in temperature $\left(20-23^{\circ} \mathrm{C}\right)$, humidity (40-60\%) and light (12 h of light, $12 \mathrm{~h}$ of dark)-regulated rooms, with water and food intake available ad libitum.

\subsection{Real-time reverse transcription polymerase chain reaction (RT-PCR) studies}

On selected days of late pregnancy (days 18, 20 and 22), rats were killed by $\mathrm{CO}_{2}$ inhalation, the uteri were excised and trimmed of fat, the feto-placental units were removed and the endometrium was denuded. The tissue samples were frozen immediately in liquid nitrogen, and then stored at $-80{ }^{\circ} \mathrm{C}$ until analysis. The frozen samples were ground with a Micro-Dismembrator $\mathrm{S}$ homogeniser (Sartorius, Germany), and the total RNA was isolated with the TRIsure Kit according to the manufacturer's instructions. RNA purity was controlled via the optical density at $260 / 280 \mathrm{~nm}$ with a BioSpec Nano instruments (Shimadzu, Japan); all samples exhibited an absorbance ratio in the range 1.6-2.0. RNA quality and integrity were assessed by agarose gel electrophoresis. One microgram of each sample of total RNA was used for reverse transcription and amplification (TaqMan RNA-to- $\mathrm{C}_{\mathrm{T}}$ 1-Step Kit and the Sensi FAST Probe Hi-Rox One-Step Kit). The following primers were used: assay ID Rn01637101_m1 for PNOC, Rn 00667869_m1 for $\beta$-actin and Rn 01775763_g1 for GAPDH as endogenous controls. RT-PCR was performed by using the ABI StepOne Real-Time cycler. The fluorescence intensities of the probes were plotted against
PCR cycle numbers. The amplification cycle displaying the first significant fluorescence signal increase was defined as the threshold cycle $\left(C_{\mathrm{T}}\right)$.

There is an ongoing debate about the applicability of beta-actin as a gene reference in the pregnant rat uterus, with no reassuring conclusion as yet (Kelly et al., 2003). Thus we have repeated our PCR studies also with GAPDH as a gene reference. We did not find differences in the change of PNOC mRNA when GAPDH was used as compared with beta-actin.

\subsection{Radioimmunoassay (RIA) for nocistatin in the rat uterus and plasma}

In RIA studies, blood and uterine samples from non-pregnant and 15-, 18-, 20- and 22-day pregnant rats were used.

Blood was collected in $\mathrm{K}_{3}$-EDTA containing vacutainers (OMKER, Hungary) and Aprotinin $(0.6 \mathrm{TIU} / \mathrm{ml})$ was added immediately as a protease inhibitor. Plasma was separated by centrifugation at $3000 \mathrm{rpm}$ for $10 \mathrm{~min}$ and samples were kept frozen at $-80{ }^{\circ} \mathrm{C}$ until direct analysis by radioimmunoassay (RIA).

$1000 \mu \mathrm{l}$ aliquots of plasma samples were mixed with equal volume of $1 \% \mathrm{v} / \mathrm{v}$ trifluoroacetic acid (TFA I.), centrifuged at $1600 \mathrm{~g}$ for $20 \mathrm{~min}$ at $4{ }^{\circ} \mathrm{C}$. The acidified samples were loaded onto C18 Sep-Pack cartridges (ABL\&E JASCO Hungary Ltd.), washed twice with TFA I., and then eluted with $60 \%$ acetonitrile in $0.1 \%$ TFA. Samples were freeze dried by centrifugation (SAVANT, Instruments, Inc., Farmingdale, NY, USA). The reconstituted eluate was subjected to RIA using commercially available ${ }^{125}$ I-Nocistatin RIA kit with minimum sensitivity of $10 \mathrm{pg} / \mathrm{ml}$. Data were evaluated by RIA-Mat 280 (Byk-Sangtec, Dietzenbach, Germany).

Extraction of nocistatin was carried out by a validated method adapted from Eun-Mee et al. (1999) and Hofbauer et al. (2000). Uterus samples were treated with $1 \mathrm{M}$ acetic acid $(250 \mathrm{mg} / \mathrm{ml})$, placed in a $95{ }^{\circ} \mathrm{C}$ water bath for $5 \mathrm{~min}$ then cooled in ice-cold water bath for $10 \mathrm{~min}$ and homogenised by an Ultra Turrax T25 Janke\&Kunkel homogeniser (IKA Labortechnik, Staufen, Germany) at 20,000 rpm for $10 \mathrm{~s}$, followed by an ultrasound homogenisation (Labsonic 2000, B.Braun, AG, Melsungen Germany) for $10 \mathrm{~s}$. Samples were replaced in the $95{ }^{\circ} \mathrm{C}$ water bath for $5 \mathrm{~min}$ then cooled in ice-cold water bath, and centrifuged at $4{ }^{\circ} \mathrm{C}$ for $10 \mathrm{~min}$ at $12,000 \mathrm{~g}$ in an Eppendorf centrifuge (A. Hettich, Tuttlingen, Germany). Aliquots of $1.0 \mathrm{ml}$ from the supernatants were treated as described for plasma samples.

During the validation of the extraction procedure stability of nocistatin, reproducibility, recovery and linearity of recovery in the $10-500 \mathrm{pg} / 100 \mathrm{mg}$ tissue concentration range were determined. Recovery was $89 \pm 0.87 \%$, and all the other parameters were in the normal range.

\subsection{In vitro contractility studies}

\subsubsection{Uterus preparation}

On day 22 of pregnancy (at term), the rats were killed by $\mathrm{CO}_{2}$ inhalation, and the uteri were removed and prepared for the in vitro contractility assay as reported previously (Klukovits et al., 2010). Briefly, the isolated uterine horns were immediately placed in an organ bath (de Jongh solution; containing in mM: $137 \mathrm{NaCl}$, $3 \mathrm{KCl}, 1 \mathrm{CaCl}_{2}, 1 \mathrm{MgCl}_{2}, 12 \mathrm{NaHCO}_{3}, 4 \mathrm{Na}_{2} \mathrm{HPO}_{4}, 6$ glucose; $\mathrm{pH} 7.4$ ) perfused with a mixture of $95 \%$ oxygen and $5 \%$ carbon dioxide (carbogen) and trimmed of fat, and the feto-placental units were removed. The temperature was maintained at $37^{\circ} \mathrm{C}$. Four rings $0.5 \mathrm{~cm}$ long were sliced from the middle part of each horn, including implantation sites, and tested in parallel; they were mounted vertically in the above-mentioned organ bath containing $10 \mathrm{ml}$ of de Jongh solution. After mounting, the initial tension was 
set at $1.5 \mathrm{~g}$ and the rings were equilibrated for $60 \mathrm{~min}$, with a solution change every $15 \mathrm{~min}$.

\subsubsection{Nocistatin studies}

In the isolated uterine rings, rhythmic contractions were elicited with $25 \mathrm{mM} \mathrm{KCl}$ or with $10 \mathrm{nM}$ oxytocin or with $1 \mu \mathrm{M}$ $\mathrm{PGF}_{2 \alpha}$. Without washing out the contractile agents, the effects of nocistatin on the uterine contractions were tested in the concentration range $10^{-12}-10^{-6} \mathrm{M}$, in a noncumulative manner (as regards its peptide characteristic). After each concentration of nocistatin, the rings were washed 3 times, allowed to recover for $5 \mathrm{~min}$, and then contracted again with the above-mentioned agents. Following the oxytocin- and $\mathrm{PGF}_{2 \alpha}$-induced contractions, the contractioninhibitory effect of nocistatin was also investigated in the presence of N/OFQ $\left(10^{-8} \mathrm{M}\right)$.

Following the $\mathrm{KCl}$-induced contractions, the contraction-inhibitory effect of nocistatin was investigated in the presence of N/OFQ $\left(10^{-8} \mathrm{M}\right)$ and/or naloxone $\left(10^{-8} \mathrm{M}\right)$. The most potent inhibitory effect of nocistatin was found in the $\mathrm{KCl}$-induced contractions; this agent was therefore used to investigate the possible mechanism of nocistatin in further studies. As naloxone induces an increase in inward $\mathrm{Ca}^{2}$ ${ }^{+}$currents (Kai et al., 2002), we conducted a series of experiments in a low $\mathrm{Ca}^{2+}$ environment in order to investigate whether the inhibitory effect of naloxone on the nocistatin-induced uterus relaxation is mediated by the opening of inward rectifying $\mathrm{Ca}^{2+}$ channels. Thus the joint effect of nocistatin and naloxone was studied in a modified de Jongh buffer, containing half the $\mathrm{Ca}^{2+}$ concentration $(0.5 \mathrm{mM}$ $\mathrm{CaCl}_{2}$ ) of the standard de Jongh buffer (Hajagos-Tóth et al., 2009). In order to investigate the participation of the outward rectifying $\mathrm{K}^{+}$channels in mediating the effects of nocistatin, tests were performed in the presence of the $\mathrm{K}_{\mathrm{Ca}} 1.1$ channel-selective blocker paxilline $\left(5 \times 10^{-6} \mathrm{M}\right)$, against spontaneous uterine contractions.

The possible involvement of the sensory neuropeptide CGRP in the actions of nocistatin was also tested on uterine tissue. In this set of experiments, capsaicin ( $1 \mu \mathrm{M}$ dissolved in physiological saline containing 6\% Tween 80 and $8 \%$ ethanol; for $10 \mathrm{~min}$ ) was used to deplete CGRP from the uterine sensory nerve endings (Holzer, 1991). After thorough washing out, the tissues were incubated with CGRP $(0.1 \mu \mathrm{M} ; 20 \mathrm{~min})$ (Sams-Nielsen et al., 2001) and washed again, and the effects of nocistatin were tested as above. These experiments were performed in a de Jongh solution supplemented with protease inhibitors such as phenylmethanesulfonyl fluoride $(1 \mu \mathrm{M})$, captopril $(0.1 \mathrm{mM})$, dithiothreitol $(0.5 \mathrm{mM})$, soy bean trypsin inhibitor $(1 \mathrm{mM})$ and aprotinin (36,000 kIU/l).

The tension of the myometrial rings was measured with a strain gauge transducer (SG-02, Experimetria Ltd., Budapest, Hungary), and recorded and analysed with the SPEL Advanced ISOSYS Data Acquisition System (Experimetria Ltd., Budapest, Hungary). The areas under the curves of 4-min periods were evaluated; the effects of nocistatin, N/OFQ and naloxone were expressed as percentages of $\mathrm{KCl} /$ oxytocin/ $\mathrm{PGF}_{2 \alpha}$-induced or spontaneous contractions. The dose-response curves were fitted and the geometrical mean of $\log \mathrm{EC}_{50}$ values and maximum contraction-inhibitory values were calculated with the Prism 4.0 computer programme (GraphPad Inc., San Diego, CA, USA).

\subsection{Measurement of uterine cAMP accumulation}

As cAMP elevation plays a major role in the relaxation of uterine smooth muscle, we set out to investigate its possible involvement in the nocistatin signalling. Uterine tissue samples were incubated in de Jongh solution at $37^{\circ} \mathrm{C}$, perfused with carbogen. cAMP accumulation was determined in the presence of the nonspecific phosphodiesterase inhibitor 3-isobutyl1-methylxanthine (IBMX; $\left.10^{-3} \mathrm{M} ; 10 \mathrm{~min}\right)$, nocistatin $\left(10^{-8} \mathrm{M}\right.$;
$10 \mathrm{~min}$ ) alone or in combination with $\mathrm{N} / \mathrm{OFQ}\left(10^{-8} \mathrm{M}\right)$ or naloxone $\left(10^{-8} \mathrm{M}\right)$, and the adenylyl cyclase activator forskolin $\left(10^{-5} \mathrm{M}\right.$; $10 \mathrm{~min})$. The samples were then immediately frozen in liquid nitrogen and stored until the extraction of cAMP. Frozen tissue samples were ground, weighed, homogenised in 10 volumes of ice-cold 5\% trichloroacetic acid and centrifuged at $1000 \mathrm{~g}$ for $10 \mathrm{~min}$. The supernatants were extracted with 3 volumes of water-saturated diethyl ether. After drying, the extracts were stored at $-80{ }^{\circ} \mathrm{C}$ until the cAMP assay. Uterine cAMP accumulation was measured with a commercial competitive cAMP enzyme immunoassay (EIA) kit and tissue cAMP levels were expressed in $\mathrm{pmol} / \mathrm{mg}$ tissue. All samples ( $n=4$ in each group) were measured in duplicate in the EIA.

\subsection{Materials}

N/OFQ and nocistatin were purchased from PolyPeptide Laboratories France SAS, Strasbourg, France. $\mathrm{PGF}_{2 \alpha}$, naloxone, forskolin, IBMX, cAMP Enzyme Immunoassay Kit, paxilline, capsaicin, soy bean trypsin inhibitor, dithiothreitol, phenylmethanesulfonyl fluoride and captopril were from Sigma-Aldrich Ltd., Budapest, Hungary. The TRIsure Kit and the Sensi FAST Probe Hi-Rox One-Step Kit were from Bioline Ltd., Budapest, Hungary. TaqMan RNA-to- $C_{T}$ 1-Step Kit, $\beta$-actin and GAPDH primers were obtained from Life Technologies, Budapest, Hungary. The ${ }^{125}$ I-Nocistatin RIA kit was from Phoenix Pharmaceuticals, Inc., purchased by Izinta Ltd., Budapest, Hungary. Aprotinin $\left(\right.$ Gordox $\left.^{\circledR}\right)$ and oxytocin were purchased from Richter Gedeon Ltd., Budapest, Hungary.

\subsection{Statistical analysis}

Statistical analyses were carried out by ANOVA Newman-Keuls multiple comparison test with the Prism 4.0 computer programme (GraphPad Inc., San Diego, CA, USA). This test makes pairwise comparisons of group means. The alpha level of Newman-Keuls test is 0.05 .

\section{Results}

\subsection{Measurement of PNOC MRNA in the uterus}

The myometrial PNOC mRNA levels increased significantly as term was approached. The PCR study showed that the levels of PNOC mRNA/ $\beta$-actin mRNA and PNOC mRNA/GAPDH mRNA were the lowest on pregnancy day 18. The relative expression of $P N O C$

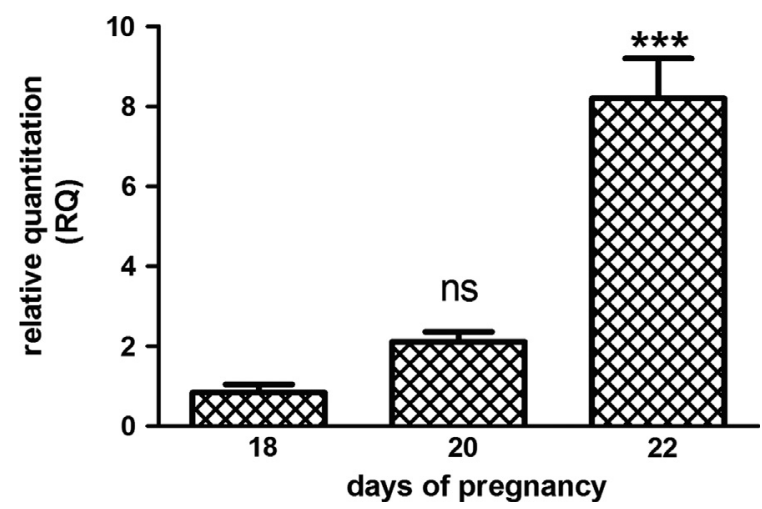

Fig. 1. Levels of expression of $P N O C$ mRNA in the rat uterus on days 18,20 and 22 of pregnancy. As term was approached, the $P N O C$ mRNA level increased; there was a significant increase in the level of $P N O C$ mRNA in uterus samples obtained from rats on day 22 (i.e. at term) as compared with that on day 20 of pregnancy $(n=3)$; $* * * P<0.001$, ns: non-significant. Significances are expressed relative to the previous column. The endogenous control is $\beta$-actin. 
mRNA on day 20 was not different from that on day 18 , but it was increased significantly by day 22 , the day of delivery; $P<0.001$ (Fig. 1, the endogenous control was $\beta$-actin; we observed the same results with $G A P D H$, data not shown).

\subsection{Measurement of nocistatin in the uterus and the plasma}

The myometrial nocistatin levels increased significantly as term was approached. The RIA experiments revealed that the levels of nocistatin were relatively low on pregnancy days 15,18 and 20 $(P>0.05)$, then elevated significantly by day 22 , the day of delivery; $P<0.05$ as compared with day 20 (Table 1 ). The nocistatin levels on day 22 did not differ from the non-pregnant samples. The plasma levels of nocistatin did not change as term was approached (days 15, 18, 20 and 22; $P>0.05$ in all comparisons).

Table 1

Tissue and plasma nocistatin levels in non-pregnant, 15, 18, 20 and 22 day pregnant rats $(n=6)$.

\begin{tabular}{lllll}
\hline Tissue & $\begin{array}{l}\text { pg/100 } \mathbf{~ m g ~ u t e r i n e} \\
\text { tissue } \pm \text { S.E.M }\end{array}$ & $\begin{array}{l}\text { pg/ml plasma } \pm \\
\text { S.E.M }\end{array}$ & \\
\hline Non-pregnant & $47.07 \pm 4.66$ & & $12.07 \pm 1.53$ & \\
15 day pregnant & $17.49 \pm 4.41$ & $\mathrm{a}$ & $14.11 \pm 1.63$ & $\mathrm{~ns}$ \\
18 day pregnant & $17.15 \pm 3.03$ & $\mathrm{~ns}$ & $11.52 \pm 1.62$ & $\mathrm{~ns}$ \\
20 day pregnant & $13.95 \pm 1.82$ & $\mathrm{~ns}$ & $12.19 \pm 1.57$ & $\mathrm{~ns}$ \\
22 day pregnant & $42.11 \pm 6.27$ & $\mathrm{a}$ & $17.59 \pm 2.12$ & $\mathrm{~ns}$ \\
\hline
\end{tabular}

${ }^{a} P<0.05$, ns: nonsignificant. Significances are expressed relative to the value of the previous tested day.

\subsection{In vitro contractility studies}

3.3.1. Investigation of the contraction-inhibitory effects of nocistatin

The contraction-inhibitory effect of nocistatin was investigated in three different agonist-induced contractions (Fig. 2). The oxytocin-, $\mathrm{PGF}_{2 \alpha^{-}}$or $\mathrm{KCl}$-stimulated contractions did not decrease significantly through the experiment. Oxytocin was able to contract the uterine smooth muscle, but in the presence of oxytocin, nocistatin alone or in the presence of N/OFQ $\left(10^{-8} \mathrm{M}\right)$ did not significantly reduce the contractions (data not shown). In the case of $\mathrm{PGF}_{2 \alpha}$-induced contractions, nocistatin and N/OFQ displayed slight inhibitory effects (Fig. 3). There was no significant difference between the $\log \mathrm{EC}_{50}$ values. Nocistatin alone decreased the $\mathrm{KCl}$-induced contractions concentration-dependently. Coadministration of N/OFQ $\left(10^{-8} \mathrm{M}\right)$ with nocistatin, however, significantly increased the maximum contraction-inhibitory effect of nocistatin; $P<0.05$ (Fig. 4A). There was no significant difference between the $\log \mathrm{EC}_{50}$ values (Table 2 ). The most potent inhibitory effect of nocistatin was found in the $\mathrm{KCl}$-induced contractions; this agent was therefore used to investigate the possible mechanism of nocistatin in further studies.

3.3.2. Investigation of the contraction-inhibitory effects of nocistatin and naloxone in a standard and a $\mathrm{Ca}^{2+}$-poor environment

In standard de Jongh solution, the maximum inhibitory effect of nocistatin was decreased by naloxone $\left(10^{-8} \mathrm{M}\right) ; P<0.001$. There was no significant difference between the $\log \mathrm{EC}_{50}$ values (Table 3 ). Naloxone also decreased the maximum contraction-inhibitory effect

A

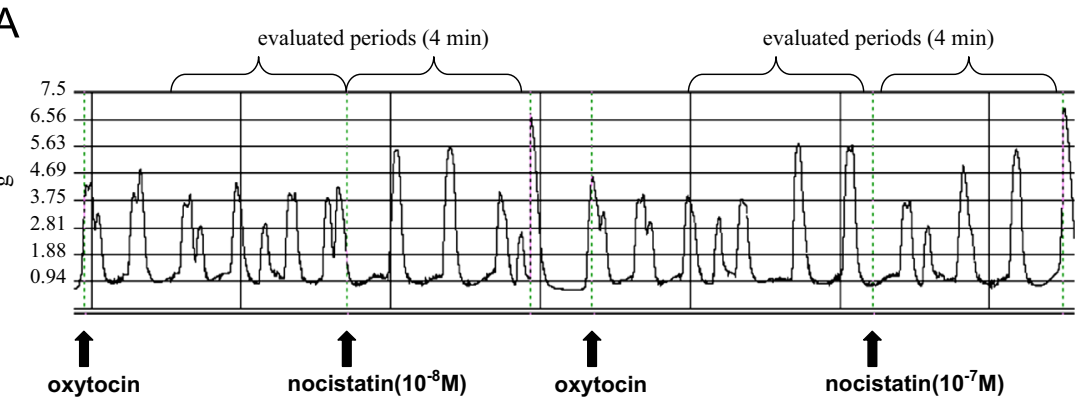

B
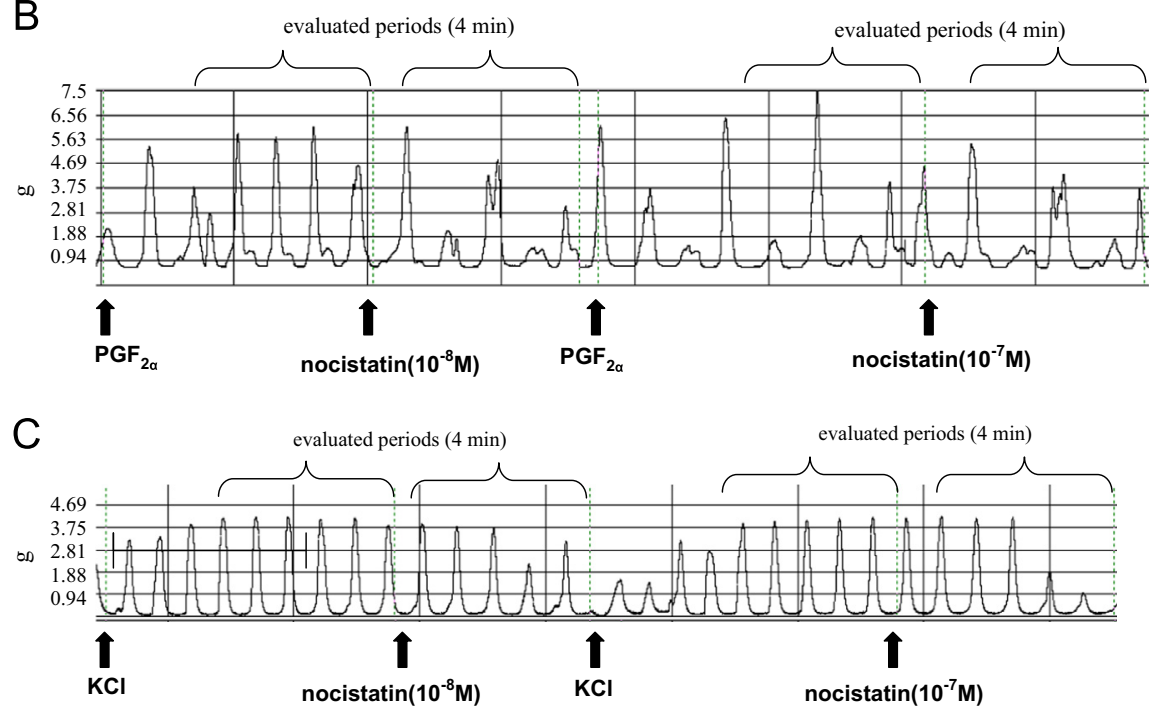

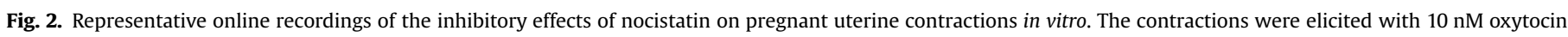

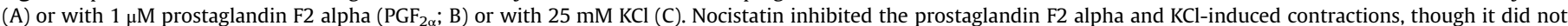
alter the oxytocin-evoked contractions. 


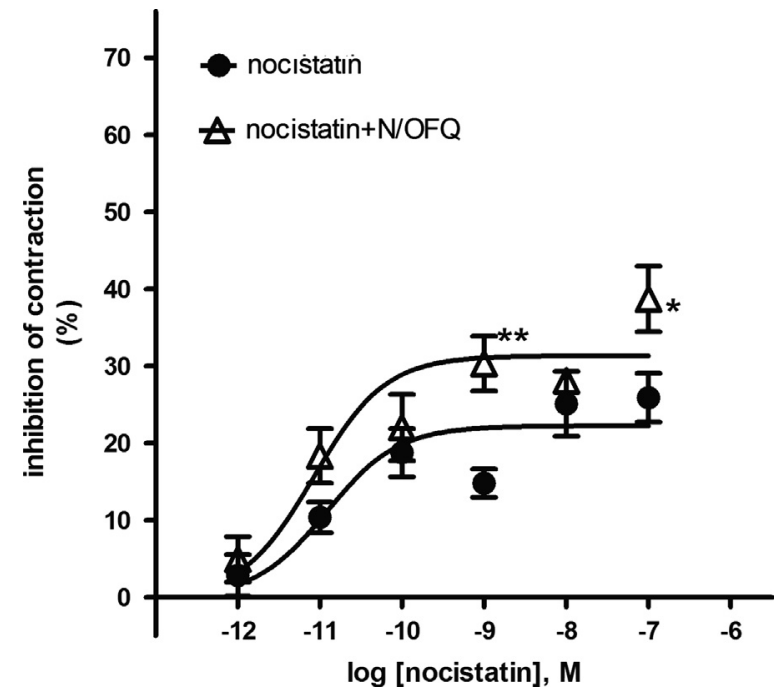

Fig. 3. Inhibitory effects of nocistatin and nociceptin (N/OFQ) on pregnant uterine contractions in vitro. The contractions were elicited with $1 \mu \mathrm{M}$ prostaglandin F2 alpha. The concentration-dependent inhibitory effect of nocistatin $(\bullet)$ was increased by $\mathrm{N} / \mathrm{OFQ}(\Delta) ; n=6$.

of the combination nocistatin+N/OFQ; $P<0.05$ (Fig. 4A). There was no significant difference between the $\log \mathrm{EC}_{50}$ values (Table 2 ).

In the $\mathrm{Ca}^{2+}$-poor environment, the concentration-response curves of nocistatin alone and of nocistatin in combination with naloxone were both shifted to the left as compared with the curves in standard de Jongh solution. The $\log \mathrm{EC}_{50}$ values of nocistatin alone and of nocistatin with naloxone were significantly lower in the $\mathrm{Ca}^{2+}$-poor environment than in standard de Jongh solution $(P<0.05)$. At the same time, naloxone did not decrease the inhibitory effect of nocistatin in the $\mathrm{Ca}^{2+}$-poor environment as it did in the standard buffer. The maximum contraction-inhibitory effect of nocistatin alone did not differ from that of nocistatin in combination with naloxone in the $\mathrm{Ca}^{2+}$-poor buffer (Fig. $4 \mathrm{~B}$ and Table 3).

\subsubsection{Investigation of the role of $K_{\mathrm{Ca}} 1.1$ channels in mediating the effects of nocistatin}

The effects of nocistatin on the spontaneous contractions of the term-pregnant rat uterus were also tested in the presence of the selective $\mathrm{K}_{\mathrm{Ca}} 1.1$ channel inhibitor paxilline $\left(5 \times 10^{-6} \mathrm{M}\right)$, (Fig. 5). In the presence of paxilline, the maximum contraction-inhibitory effect of nocistatin $\left(E_{\max }: 33.04 \pm 2.83 \%\right.$ ) was decreased significantly ( $E_{\max }: 11.15 \pm 3.61 \% ; P<0.001$ ), while there was no significant difference between the $\log \mathrm{EC}_{50}$ values $\left(\log \mathrm{EC}_{50}\right.$ : $-8.29 \pm 0.45$ and $-9.47 \pm 0.93)$.

\subsubsection{Investigation of the role of CGRP in mediating the effects of nocistatin}

Since the exact site of action of nocistatin is still unclear, we tested whether it might act by modulating neuropeptide release from capsaicin-sensitive sensory nerve endings in the pregnant rat uterus. Neuropeptide depletion from the capsaicin-sensitive primary afferents was induced with capsaicin (Fig. 6). The maximum contraction-inhibitory effect of nocistatin was decreased significantly $(P<0.01)$ after preincubation with capsaicin $(1 \mu \mathrm{M}$; Table 4). The solvent of capsaicin (control) did not change the effect of nocistatin $(P>0.05)$.

When the neuropeptide depletion was followed by the addition of CGRP $(0.1 \mu \mathrm{M})$, the maximum contraction-inhibitory effect of nocistatin was significantly higher than after incubation with

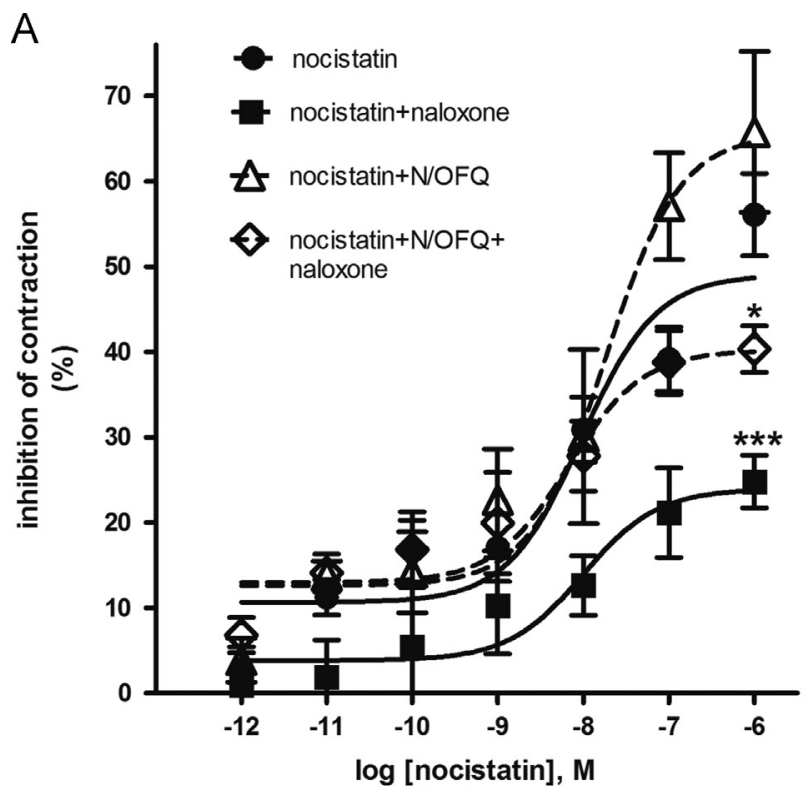

$\mathrm{B}$

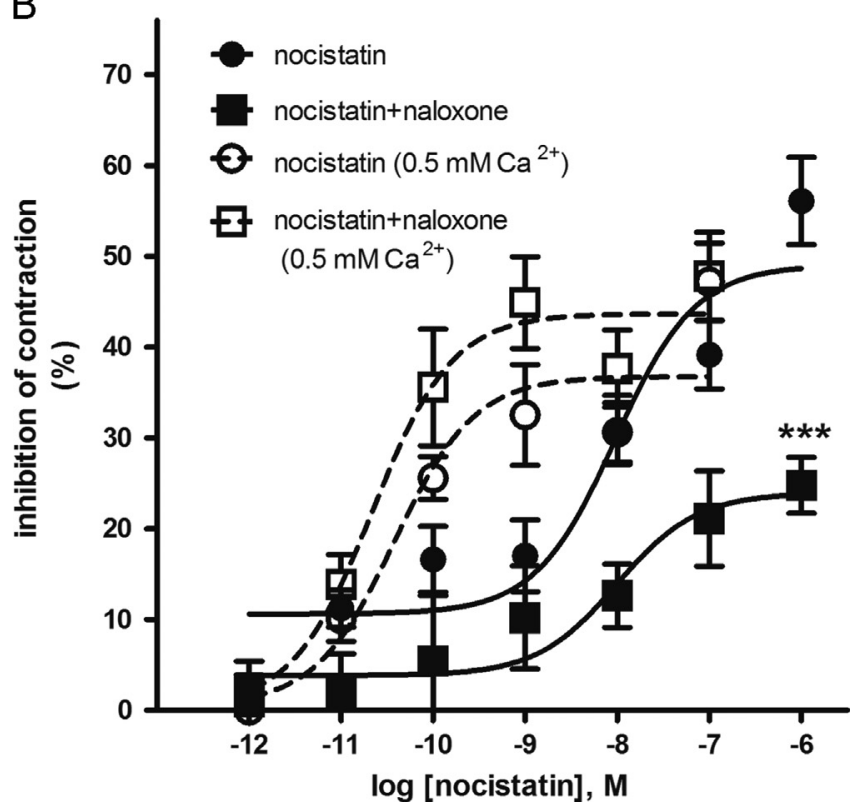

Fig. 4. Effects of nocistatin and naloxone on pregnant uterine contractions in a standard and a low $\mathrm{Ca}^{2+}$ environment in vitro. The contractions were elicited with $25 \mathrm{mM} \mathrm{KCl}$ in 22-day-pregnant rat uterine rings. The concentration-dependent inhibitory effect of nocistatin $(\bullet)$ was significantly attenuated by naloxone $(\bullet)$; $n=10$. When nocistatin, N/OFQ and naloxone were present, the joint effect of the three drugs $(\diamond)$ was decreased as compared with the dual effect of nocistatin and $\mathrm{N} / \mathrm{OFQ}(\Delta) ; n=6(\mathrm{~A})$. The concentration-dependent inhibitory effect of nocistatin ( $\circ)$ was not altered by naloxone $(\square)$ in the $\mathrm{Ca}^{2+}$-poor buffer, whereas it was inhibited in the standard $\mathrm{Ca}^{2+}$-containing buffer ( $\bullet$ nocistatin; - naloxone); $n=6(\mathrm{~B})$.

capsaicin $(P<0.01)$. The addition of CGRP restored the inhibitory effect of nocistatin as compared with the control $(P>0.05)$.

\subsection{Measurement of uterine cAMP accumulation}

We also investigated whether cAMP accumulation plays a role in the contraction-inhibitory effect of nocistatin (Fig. 7). Nocistatin evoked a significant increase $(P<0.001)$ in the uterine cAMP level $(15.12 \pm 0.40 \mathrm{pmol} / \mathrm{mg}$ tissue $)$ as compared with the basic activity (12.82 $\pm 0.17 \mathrm{pmol} / \mathrm{mg}$ tissue). Co-administration of N/OFQ with nocistatin caused a further elevation in the cAMP level 
Table 2

$\log \mathrm{EC}_{50}$ and maximum contraction-inhibitory values of nocistatin alone and in the presence of nociceptin (N/OFQ) on prostaglandin $\mathrm{F}_{\alpha}\left(\mathrm{PGF}_{2 \alpha}\right)$ or $\mathrm{KCl}$-stimulated contractions; and of nocistatin with $\mathrm{N} / \mathrm{OFQ}+$ naloxone on $\mathrm{KCl}$-stimulated contractions in the 22-day-pregnant rat uterus in vitro $(n=8)$.

\begin{tabular}{lllll}
\hline Substance & $\begin{array}{l}\log \mathbf{E C}_{\mathbf{5 0}} \\
( \pm \text { S.E.M.) }\end{array}$ & $\begin{array}{l}\boldsymbol{E}_{\mathbf{m a x}} \\
(\% \pm \text { S.E.M.) }\end{array}$ \\
\hline Nocistatin (on $\mathrm{PGF}_{2 \alpha}$-evoked contraction) & $-10.92 \pm 0.22$ & $25.90 \pm 3.16$ & \\
Nocistatin+N/OFQ & $-11.07 \pm 0.21$ & ns & $38.71 \pm 4.26$ & a \\
Nocistatin (on KCl-evoked contraction) & $-8.02 \pm 0.18$ & & $56.10 \pm 4.82$ & \\
Nocistatin+N/OFQ & $-7.75 \pm 0.27$ & ns & $65.78 \pm 9.42$ & a \\
Nocistatin+N/OFQ+naloxone & $-8.17 \pm 0.27$ & b & $40.33 \pm 2.73$ & c \\
\hline
\end{tabular}

${ }^{a} P<0.05$, ns: nonsignificant; significances are expressed relative to nocistatin alone.

b Nonsignificant; significances are expressed relative to nocistatin in the presence of $\mathrm{N} / \mathrm{OFQ}$.

${ }^{c} P<0.05$.

Table 3

$\log \mathrm{EC}_{50}$ and maximum contraction-inhibitory effects of nocistatin alone and in the presence of naloxone on $\mathrm{KCl}$-stimulated uterine contractions in the 22-daypregnant rat in vitro, either in standard $\mathrm{Ca}^{2+}$-containing or in $\mathrm{Ca}^{2+}$-poor de Jongh solutions $(n=6)$.

\begin{tabular}{lcccc}
\hline Substance & $\log _{\mathbf{E 0}}( \pm$ S.E.M. $)$ & $\boldsymbol{E}_{\mathbf{m a x}}(\% \pm$ S.E.M. $)$ \\
\hline Nocistatin $\left(1 \mathrm{mM} \mathrm{Ca}^{2+}\right)$ & $-8.02 \pm 0.18$ & & $56.10 \pm 4.82$ & \\
Nocistatin+naloxone $\left(1 \mathrm{mM} \mathrm{Ca}^{2+}\right)$ & $-8.01 \pm 0.47$ & ns & $24.78 \pm 3.08$ & a \\
Nocistatin $\left(0.5 \mathrm{mM} \mathrm{Ca}^{2+}\right)$ & $-10.42 \pm 0.23$ & b & $47.21 \pm 4.27$ & \\
Nocistatin+naloxone $\left(0.5 \mathrm{mM} \mathrm{Ca}^{2+}\right)$ & $-10.66 \pm 0.24$ & ns; ${ }^{b}$ & $47.82 \pm 4.85$ & ns \\
\hline
\end{tabular}

${ }^{a} P<0.001$, ns: nonsignificant. The significances of the joint effect of nocistatin +naloxone are expressed relative to nocistatin alone in the same $\mathrm{Ca}^{2+}$-containing de Jongh solution.

${ }^{\mathrm{b}} \mathrm{P}<0.05$; significances are expressed relative to the same substance in a different $\mathrm{Ca}^{2+}$-containing de Jongh solution.

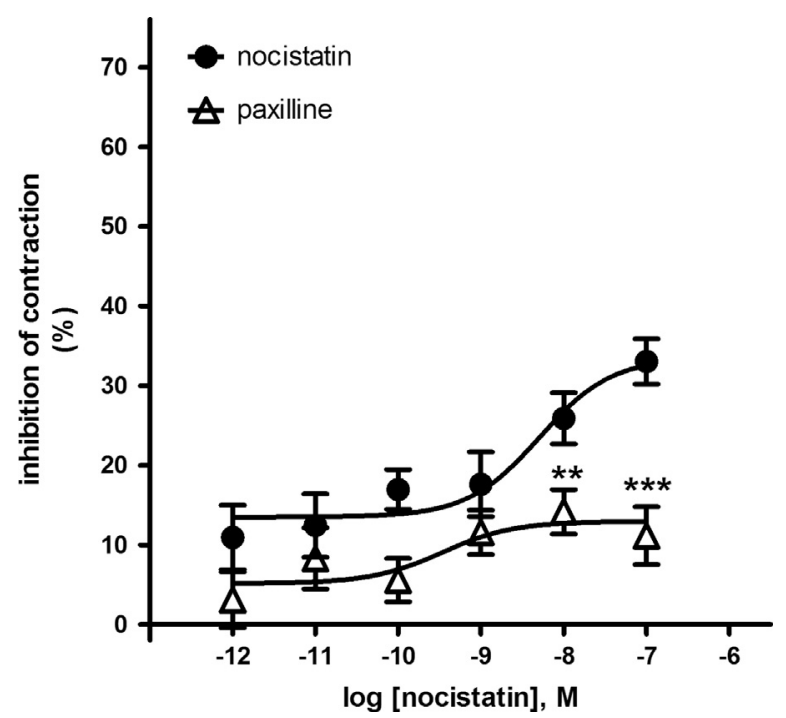

Fig. 5. Effects of paxilline on the contraction-inhibitory effect of nocistatin in vitro. The spontaneous contractions were recorded in 22-day-pregnant uterine rings from the rat. The concentration-dependent inhibitory effect of nocistatin $(\bullet)$ was decreased by paxilline $(\Delta) ; n=8$.

$(17.48 \pm 0.29 \mathrm{pmol} / \mathrm{mg}$ tissue; $P<0.01)$. However, when naloxone was co-administered with nocistatin, a significant decrease was detected in the cAMP level $(13.35 \pm 0.52 \mathrm{pmol} / \mathrm{mg}$ tissue $)$ as compared with the effect of nocistatin alone $(P<0.05)$.

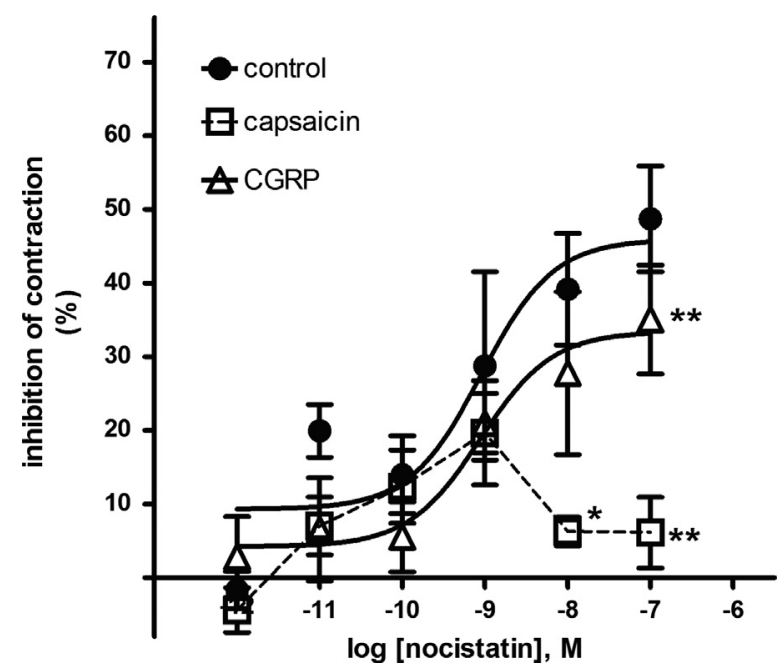

Fig. 6. The role of calcitonin gene-related peptide (CGRP) on the contractioninhibitory effect of nocistatin in vitro. The contractions were elicited with $25 \mathrm{mM}$ $\mathrm{KCl}$ in 22-day-pregnant rat uterine rings. The concentration-dependent inhibitory effect of nocistatin ( $\bullet$; control) was reduced significantly after preincubation with capsaicin $(\square ; 1 \mu \mathrm{M})$. Addition of CGRP $(0.1 \mu \mathrm{M})$ after preincubation with capsaicin caused a significant elevation of the concentration-response curve of nocistatin $(\Delta)$; $n=6$.

\section{Discussion}

Many studies have been reported on the central effects of nocistatin, but none on the peripheral effects of nocistatin. We earlier described the uterus-relaxant effect of N/OFQ a peptide derived from the same precursor as nocistatin (Klukovits et al., 2010). Nocistatin displays opposite effects to those of N/OFQ in the central nervous system. Our present aims were to determine the peripheral effects of nocistatin on the rat uterus in vitro, and to elucidate its signalling mechanism.

PNOC mRNA is expressed predominantly in the central nervous system (the brain and spinal cord). A previous study also confirmed its presence in human peripheral blood mononuclear cells (Williams et al., 2008), and it has been detected in the rat ovary (Mollereau et al., 1996; Leo et al., 2001). However, the expressions of PNOC mRNA and nocistatin have not been investigated to date in the uterus. We found that the common precursor for N/OFQ and nocistatin, the PNOC mRNA, is expressed locally in the pregnant rat uterus, indicating that N/OFQ and nocistatin are synthesised locally. This finding justifies a local regulatory role for these pronociceptive peptides, in the term pregnant rat uterus.

In addition, we detected the presence of nocistatin in the pregnant and non-pregnant rat uterus. Both the expressions of PNOC mRNA and of nocistatin were high on the last day of pregnancy, as compared with earlier days. Furthermore, we found that nocistatin in the pregnant rat uterus at term is about 10 times more abundant than N/OFQ so it seems that PNOC mRNA is translated mainly to nocistatin, rather than N/OFQ. The plasma level of nocistatin did not change at the end of pregnancy, which further confirms the local origin of nocistatin in the uterus.

After confirming that N/OFQ is effective in inhibiting uterine contractions (Klukovits et al., 2010), we investigated whether nocistatin influences the uterine smooth muscle in vitro. Although nocistatin possesses a contraction-inhibitory effect on $\mathrm{KCl}-$ and $\mathrm{PGF}_{2 \alpha^{-}}$ evoked contractions, its action against $\mathrm{PGF}_{2 \alpha}$ was weak. N/OFQ was able to potentiate the inhibitory effect of nocistatin in both cases. Nocistatin does not counteract the effects of N/OFQ on the myometrium contractility, as was presumed in previous studies relating to their actions in the central nervous system. However, nocistatin was ineffective on oxytocin-induced contractions. This phenomenon will 
Table 4

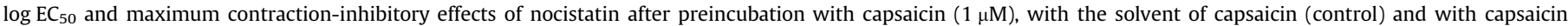
$(1 \mu \mathrm{M})$ and CGRP $(0.1 \mu \mathrm{M})(n=6)$.

\begin{tabular}{|c|c|c|}
\hline Substance & $\log \mathrm{EC}_{50}( \pm$ S.E.M. $)$ & Max. inhibition at $10^{-7} \mathrm{M}$ nocistatin (\% \pm S.E.M.) \\
\hline Nocistatin control & $-9.04 \pm 0.43$ & $48.72 \pm 7.18$ \\
\hline Nocistatin preincubated with capsaicin & Not converged & $6.14 \pm 4.79$ \\
\hline Nocistatin preincubated with capsaicin and CGRP & $-9.06 \pm 0.46$ & $35.05 \pm 7.38$ \\
\hline
\end{tabular}

${ }^{a} P<0.01$. Significances after preincubation with capsaicin are expressed relative to nocistatin alone, and significances after preincubation with capsaicin and CGRP \&QJ; are expressed relative to preincubation with capsaicin alone.

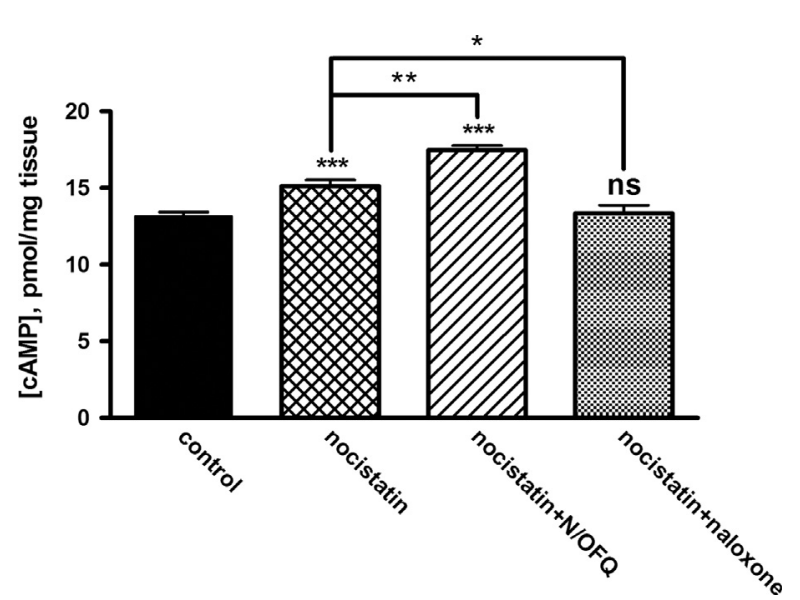

Fig. 7. Effects of nocistatin on intracellular cAMP levels in the pregnant rat uterus. Nocistatin caused a significant elevation in cAMP level as compared with the control (black column); ${ }^{* * *} P<0.001$. The presence of N/OFQ increased $(* * P<0.01$ ), while naloxone decreased $\left({ }^{*} P<0.05\right)$ the nocistatin-induced intracellular cAMP accumulation.

be discussed later with regard to a detailed mechanism of the action of nocistatin on the pregnant rat myometrium.

Naloxone inhibits the contraction-inhibitory effect of nocistatin against $\mathrm{KCl}$-induced contractions. Nocistatin does not bind to any of the classical opioid receptors, or to the NOP receptor (Johnson and Connor, 2007; Fantin et al., 2007), thus this inhibition is not likely to be mediated by opioid receptors. It was demonstrated that naloxone induces an increase in inward $\mathrm{Ca}^{2+}$ currents (Kai et al., 2002). These findings led us to investigate whether the inhibitory effect of naloxone on nocistatin-induced uterus relaxation is mediated by the opening of inward rectifying $\mathrm{Ca}^{2+}$ channels. To test our hypothesis, we used a $\mathrm{Ca}^{2+}$-poor environment, where naloxone did not inhibit the effect of nocistatin. We presume that, in a low extracellular $\mathrm{Ca}^{2+}$ concentration, naloxone is probably unable to promote a $\mathrm{Ca}^{2+}$ influx, and hence it cannot overcome the relaxation induced by nocistatin. The leftward shift in the concentration-response curves are likely to be due to the weaker tissue contractility, caused by the lower $\mathrm{Ca}^{2+}$ content.

When N/OFQ was present, naloxone was able to decrease the common contraction-inhibitory effect of nocistatin and N/OFQ. However, we found earlier that naloxone increases the effect of N/OFQ (Klukovits et al., 2010). The effect seen here is probably the consequence of the more pronounced inhibitory effect of nocistatin as compared with that of N/OFQ.

After the description of the contraction-inhibitory effect of nocistatin in the in vitro contractility studies, our further aim was to investigate some of the potential nocistatin signalling pathways.

In the uterus, the plentiful $\mathrm{K}_{\mathrm{Ca}} 1.1$ channels play an important role in decreasing depolarisation, thereby relaxing the uterine smooth muscle. These channels are activated by a cAMPdependent phosphorylation pathway (Chanrachakul et al., 2004).
We set out to investigate the role of $\mathrm{K}^{+}$currents in the intracellular signalling of nocistatin. Paxilline, a selective inhibitor of the $\mathrm{K}_{\mathrm{Ca}} 1.1$ channels, inhibited the contraction-inhibitory effect of nocistatin, as evidence that the $\mathrm{Ca}^{2+}$-dependent $\mathrm{K}^{+}$channels play a role in the intracellular signalling of nocistatin.

As regards the higher contractility during delivery, the elevation of nocistatin levels in the myometrium at term appears rather contradictory, since nocistatin has uterus relaxing effect. Nevertheless, it was also reported to inhibit hyperalgesia and allodynia, thus it has a regulatory role in pain signalling, which may explain its functional importance during labour. Additionally, inflammatory mediators play a role in the initiation of labour, yet some of them (e.g. CGRP) exhibit utero-relaxant activity among their various effects.

Opioid-like nociceptive peptides have been reported to release neurotransmitters such as CGRP or substance P (SP) from capsaicinsensitive primary sensory neurons (Peiser et al., 2000; Helyes et al., 1997). These neuropeptides are synthesised in the dorsal root ganglia (DRG) cells, stored in vesicles and released by exocytosis (Lundberg, 1996) in response to electrical (Markowitz et al., 1987; Buzzi et al., 1991) or chemical stimulation (Kilo et al., 1997). CGRP has been reported to inhibit smooth muscle contractility in a variety of tissues, including the pregnant rat uterus (Pennefather et al., 1990). Other studies have reported that the binding of ${ }^{125}$ I-CGRP to rat uterine membranes was increased during pregnancy and decreased during parturition (Yallampalli et al., 1999). It is known that denervation takes place in the myometrium during pregnancy, but this process mainly affects adrenergic nerves and does not involve the sensory units, including CGRP-containing nerves (Klukovits et al., 2004).

The potential involvement of CGRP in the actions of nocistatin on the pregnant rat uterus was therefore also tested. While capsaicin causes the depletion of CGRP from sensory nerve terminals (Holzer, 1991), other studies have furnished evidence of a CGRP reload into the sensory nerve terminals after depletion by capsaicin (Sams-Nielsen et al., 2001). We investigated the effect of nocistatin either on capsaicin-induced CGRP-depleted uterus samples or on CGRP-reloaded uterus samples. Capsaicin blocked the contraction-inhibitory effect of nocistatin, which was restored after the tissue samples were incubated with CGRP. Consequently, we assume that CGRP is an important factor in the contractioninhibitory effect of nocistatin.

To support the hypothesis of the cross-talk between nocistatin and CGRP, a special population of opioid receptors in DRG neurons was reported, where low doses of opioids can provoke hyperalgesia, due to the activation of excitatory opioid receptors on the afferent nerve terminals (Crain and Shen, 2000). There is biochemical and pharmacological evidence that this phenomenon involves an increased release of excitatory neuropeptides, including CGRP and SP, in the spinal cord (Xu et al., 2003; Wiesenfeld-Hallin et al., 1991; Crain and Shen, 1990). We assume that nocistatin, similarly to opioid peptides and N/OFQ may promote the release of neuropeptides from sensory nerves (Moran et al., 2000). This mechanism may explain the ineffectiveness of nocistatin against 
oxytocin-induced contraction; it was reported that the CGRPagonist adrenomedullin also failed to block oxytocin-evoked contractions, whereas it was effective against spontaneous and bradykinin-induced contractions (Yanagita et al., 2000).

For further investigation of the mechanism by which nocistatin inhibits uterine contractions, the effect of nocistatin on uterine cAMP accumulation was measured. We detected moderate elevation of cAMP levels in the presence of nocistatin, similarly as in the case of N/OFQ. In the presence of N/OFQ with nocistatin, a further cAMP level elevation was found, which can be explained by the mutual cAMP-accumulating effects of N/OFQ and nocistatininduced CGRP liberation (Klukovits et al., 2010; Dong et al., 2005). In correlation with the in vitro contractility studies, naloxone decreased the cAMP levels elevated by nocistatin, which suggests that naloxone interferes with nocistatin at the level of G-protein activation, too.

Due to the CGRP-releasing effect of nocistatin, the relaxant mechanism seems to be an indirect pathway. On the other hand, the opening of potassium channels and inducing inward potassium current may also play a role in the regulation of the relaxing effect of nocistatin, and can be considered as direct effect on uterine smooth muscle. Thus nocistatin might have both direct and indirect dilatory effect on myometrium.

\section{Conclusions}

These results provide evidence that nocistatin alone and also in combination with N/OFQ generated locally in the uterus, exert an inhibitory effect in the rat uterus, this mechanism being mediated mainly by $\mathrm{K}_{\mathrm{Ca}} 1.1$ channels and consequent hyperpolarization, and by release of the sensory neuropeptide CGRP. Naloxone inhibits the contraction-inhibitory effect of nocistatin by activating inward rectifying $\mathrm{Ca}^{2+}$ channels and by decreasing the cAMP-accumulating effect of nocistatin. The elevated cAMP levels moderately contribute to the uterus-relaxing effect of nocistatin. This complex signalling pathway may provide an opportunity for the development of novel treatments for the inhibition of uterine contractions and hence prevent preterm birth. The findings of this in vitro study need to be evaluated under in vivo conditions, and further experiments on human tissue are necessary in order to allow conclusions on the relevance of the present findings as concerns human disease.

\section{Acknowledgement}

This work was supported by OTKA PD 100868 and by TÁMOP4.2.1/B-09/1/KONV-2010-0005. The technical support of Mónika Hantos Pharm. D. Ph.D., Ms. Ágnes Kovács and Ms Györgyi Guth is highly appreciated.

\section{References}

Anderberg, U.M., Liu, Z., Berglund, L., Nyberg, F., 1998. Plasma levels on nociceptin in female fibromyalgia syndrome patients. Z. Rheumatol. 57 (Suppl. 2), 77-80.

Buzzi, M.G., Carter, W.B., Shimizu, T., Heath 3rd, H., Moskowitz, M.A., 1991. Dihydroergotamine and sumatriptan attenuate levels of CGRP in plasma in rat superior sagittal sinus during electrical stimulation of the trigeminal ganglion. Neuropharmacology 30, 1193-1200.

Chanrachakul, B., Pipkin, F.B., Khan, R.N., 2004. Contribution of coupling between human myometrial beta2-adrenoreceptor and the $\mathrm{BK}(\mathrm{Ca})$ channel to uterine quiescence. Am. J. Physiol. Cell Physiol. 287, C1747-C1752.

Collins, J.J., Usip, S., McCarson, K.E., Papka, R.E., 2002. Sensory nerves and neuropeptides in uterine cervical ripening. Peptides 23, 167-183.

Crain, S.M., Shen, K.F., 1990. Opioids can evoke direct receptor-mediated excitatory effects on sensory neurons. Trends Pharmacol. Sci. 11, 77-81.

Crain, S.M., Shen, K.F., 2000. Antagonists of excitatory opioid receptor functions enhance morphine's analgesic potency and attenuate opioid tolerance/dependence liability. Pain 84, 121-131.
Dong, Y.L., Vegiraju, S., Yallampalli, C., 2005. $\mathrm{Ca}^{2+}$ signaling in human fetoplacental vasculature: effect of CGRP on umbilical vein smooth muscle cytosolic $\mathrm{Ca}^{2+}$ concentration. Am. J. Physiol. Heart Circ. Physiol. 289, H960-967.

Eto, K., Shiotsuki, M., Sakai, T., Abe, S., 2012. Nociceptin is upregulated by FSH signaling in Sertoli cells in murine testes. Biochem. Biophys. Res. Commun. 421, 678-683.

Eun-Mee, K., Grace, M.K., Welch, C.C., Billington, C.J., Levine, A.S., 1999. STZ-induced diabetes decreases and insulin normalizes POMC mRNA in arcuate nucleus and pituitary in rats. Am. J. Physiol. Regul. Integr. Comp. Physiol. 45 (276), R1320-R1326.

Fantin, M., Fischetti, C., Trapella, C., Morari, M., 2007. Nocistatin inhibits 5 -hydroxytryptamine release in the mouse neocortex via presynaptic $\mathrm{Gi} / \mathrm{o}$ protein linked pathways. Br. J. Pharmacol. 152, 549-555.

Foradori, C.D., Amstalden, M., Coolen, L.M., Singh, S.R., McManus, C.J., Handa, R.J., Goodman, R.L., Lehman, M.N., 2007. Orphanin FQ: evidence for a role in the control of the reproductive neuroendocrine system. Endocrinology 148, 4993-5001.

Gu, H., Hu, D., Hong, X.R., Mao, J., Cui, Y., Hui, N., Sha, J.Y., 2003. Changes and significance of orphanin and serotonin in patients with postpartum depression. Zhonghua Fu Chan Ke Za Zhi 38, 727-728. (in Chinese).

Hajagos-Tóth, J., Falkay, G., Gáspár, R., 2009. Modification of the effect of nifedipine in the pregnant rat myometrium: the influence of progesterone and terbutaline. Life Sci. 85, 568-572.

Helyes, Z., Németh, J., Pintér, E., Szolcsányi, J., 1997. Inhibition by nociceptin of neurogenic inflammation and the release of SP and CGRP from sensory nerve terminals. Br. J. Pharmacol. 121, 613-615.

Hiramatsu, M., Inoue, K., 1999. Effects of nocistatin on nociceptin-induced impairment of learning and memory in mice. Eur. J. Pharmacol. 367, 151-155.

Hofbauer, K.H., Jensen, B.L., Kurtz, A., Sandner, P., 2000. Tissue hypoxygenation activates the adrenomedullin system in vivo. Am. J. Physiol. Regul. Integr. Comp. Physiol. 278, R513-R519.

Holzer, P., 1991. Capsaicin: cellular targets, mechanisms of action, and selectivity for thin sensory neurons. Pharmacol. Rev. 43, 143-201.

Hou, R., Zhang, W.Y., Liu, L.Y., Lu, J., Zhang, W.Y., 2011. Expression of orphanin in adenomyosis and its relationship with dysmenorrhea. Zhonghua Yi Xue Za Zhi 91, 612-615.

Johnson, E.E., Connor, M., 2007. Towards a receptor for nocistatin? Br. J. Pharmacol. $152,415-416$.

Kai, L., Wang, Z.F., Hu, D.Y., Shi, Y.L., Liu, L.M., 2002. Modulation of $\mathrm{Ca}^{2+}$ channels by opioid receptor antagonists in mesenteric arterial smooth muscle cells of rats in hemorrhagic shock. J. Cardiovasc. Pharmacol. 40, 618-624.

Kelly, B.A., Bond, B.C., Poston, L., 2003. Gestational profile of matrix metalloproteinases in rat uterine artery. Mol. Hum. Reprod. 9, 351-358.

Kilo, S., Harding-Rose, C., Hargreaves, K.M., Flores, C.M., 1997. Peripheral CGRP release as a marker for neurogenic inflammation: a model system for the study of neuropeptide secretion in rat paw skin. Pain 73, 201-207.

Klukovits, A., Gáspár, R., Sántha, P., Jancsó, G., Falkay, G., 2004. Role of capsaicinsensitive nerve fibers in uterine contractility in the rat. Biol. Reprod. 70, 184-190.

Klukovits, A., Tekes, K., Gündüz Cinar, O., Benyhe, S., Borsodi, A., Deák, B.H., Hajagos-Tóth, J., Verli, J., Falkay, G., Gáspár, R., 2010. Nociceptin inhibits uterine contractions in term-pregnant rats by signaling through multiple pathways. Biol. Reprod. 83, 36-41.

Leo, C.P., Pisarska, M.D., Hsueh, A.J., 2001. DNA array analysis of changes in preovulatory gene expression in the rat ovary. Biol. Reprod. 65, 269-276.

Lundberg, J.M., 1996. Pharmacology of cotransmission in the autonomic nervous system: integrative aspects on amines, neuropeptides, adenosine triphosphate, amino acids and nitric oxide. Pharmacol. Rev. 48, 113-178.

Markowitz, S., Saito, K., Moskowitz, M.A., 1987. Neurogenically mediated leakage of plasma protein occurs from blood vessels in dura mater but not brain. J. Neurosci. 7, 4129-4136.

Martin, W.J., Malmberg, A.B., Basbaum, A.I., 1998. Pain: nocistatin spells relief. Curr. Biol. 8, R525-R527.

Minami, T., Nishihara, I., Uda, R., Ito, S., Hyodo, M., Hayaishi, O., 1994a. Characterization of EP-receptor subtypes involved in allodynia and hyperalgesia induced by intrathecal administration of prostaglandin E2 to mice. Br. J. Pharmacol. 112, 735-740.

Minami, T., Uda, R., Horiguchi, S., Ito, S., Hyodo, M., Hayaishi, O., 1994b. Allodynia evoked by intrathecal administration of prostaglandin E2 to conscious mice. Pain 57, 217-223.

Mollereau, C., Simons, M.J., Soularue, P., Liners, F., Vassart, G., Meunier, J.C., Parmentier, M., 1996. Structure, tissue distribution, and chromosomal localization of the prepronociceptin gene. Proc. Natl. Acad. Sci. USA 93, 8666-8670.

Moodley, N., Lau, W.A., Pennefather, J.N., Story, M.E., Fisher, L., 1999. NK2 receptors mediate tachykinin-induced contractions of rat uterus during the oestrous cycle. Eur. J. Pharmacol. 376, 53-60.

Moran, T.D., Abdulla, F.A., Smith, P.A., 2000. Cellular neurophysiological actions of nociceptin/orphanin FQ. Peptides 21, 969-976.

Neal Jr., C.R., Mansour, A., Reinscheid, R., Nothacker, H.P., Civelli, O., Watson Jr, S.J., 1999. Localization of orphanin FQ (nociceptin) peptide and messenger RNA in the central nervous system of the rat. J. Comp. Neurol. 406, 503-547.

Okuda-Ashitaka, E., Ito, S., 2000. Nocistatin: a novel neuropeptide encoded by the gene for the nociceptin/orphanin FQ precursor. Peptides 21, 1101-1109.

Okuda-Ashitaka, E., Minami, T., Tachibana, S., Yoshihara, Y., Nishiuchi, Y., Kimura, T., Ito, S., 1998. Nocistatin, a peptide that blocks nociceptin action in pain transmission. Nature 392, 286-289. 
Olszewski, P.K., Shaw, T.J., Grace, M.K., Billington, C.J., Levine, A.S., 2000. Nocistatin inhibits food intake in rats. Brain Res. 872, 181-187.

Peiser, C., Undem, B.J., Fischer, A., 2000. Nociceptin effects in the airways. Peptides 21, 995-998.

Pennefather, J.N., Patak, E., Pinto, F.M., Candenas, M.L., 2004. Mammalian tachykinins and uterine smooth muscle: the challenge escalates. Eur. J. Pharmacol. 500, 15-26.

Pennefather, J.N., Reynoldson, N.A., Handberg, G.M., 1990. Inhibition of rat uterine contractions by rat and human CGRP. Peptides 11, 903-906.

Popescu, L.M., Nuțu, O., Panoiu, C., Toescu, E.G., 1985. Oxytocin contracts the human uterus at term by inhibiting the myometrial $\mathrm{Ca}^{2+}$-extrusion. Biosci. Rep. 5, 21-28.

Sams-Nielsen, A., Orskov, C., Jansen-Olesen, I., 2001. Pharmacological evidence for CGRP uptake into perivascular capsaicin sensitive nerve terminals. Br. J. Pharmacol. 132, 1145-1153.

Shew, R.L., Papka, R.E., McNeill, D.L., 1991. Substance P and calcitonin gene-related peptide immunoreactivity in nerves of the rat uterus: localization, colocalization and effects on uterine contractility. Peptides 12, 593-600.

Sinchak, K., Romeo, H.E., Micevych, P.E., 2006. Site-specific estrogen and progestin regulation of orphaninFQ/nociceptin and nociceptin opioid receptor mRNA expression in the female rat limbic hypothalamic system. J. Comp. Neurol. 496, 252-268.

Taiwo, Y.O., Levine, J.D., 1988. Prostaglandins inhibit endogenous pain control mechanisms by blocking transmission at spinal noradrenergic synapses. J. Neurosci. 8, 1346-1349.
Wiesenfeld-Hallin, Z., Xu, X.J., Håkanson, R., Feng, D.M., Folkers, K., 1991. Low-dose intrathecal morphine facilitates the spinal flexor reflex by releasing different neuropeptides in rats with intact and sectioned peripheral nerves. Brain Res. 551, 157-162.

Williams, J.P., Thompson, J.P., Rowbotham, D.J., Lambert, D.G., 2008. Human peripheral blood mononuclear cells produce pre-pro-nociceptin/orphanin FQ mRNA. Anesth. Analg. 106, 865-866.

$\mathrm{Xu}, \mathrm{X} . J .$, Colpaert, F., Wiesenfeld-Hallin, Z., 2003. Opioid hyperalgesia and tolerance versus $5-\mathrm{HT}_{1 \mathrm{~A}}$ receptor-mediated inverse tolerance. Trends Pharmacol. Sci. 24, 634-639.

Yallampalli, C., Gangula, P.R., Kondapaka, S., Fang, L., Wimalawansa, S., 1999 Regulation of calcitonin gene-related peptide receptors in the rat uterus during pregnancy and labor and by progesterone. Biol. Reprod. 61, 1023-1030.

Yanagita, T., Yamamoto, R., Sugano, T., Kobayashi, H., Uezono, Y., Yokoo, H., Shiraishi, S., Minami, S.I., Wada, A., 2000. Adrenomedullin inhibits spontaneous and bradykinin-induced but not oxytocin- or prostaglandin $\mathrm{F}$ (2alpha)-induced periodic contraction of rat uterus. Br. J. Pharmacol. 130, 1727-1730.

Zádori, Z.S., Shujaa, N., Köles, L., Király, K.P., Tekes, K., Gyires, K., 2008. Nocistatin and nociceptin given centrally induce opioid-mediated gastric mucosal protection. Peptides 29, 2257-2265.

Zeilhofer, H.U., Selbach, U.M., Guhring, H., Erb, K., Ahmadi, S., 2000. Selective suppression of inhibitory synaptic transmission by nocistatin in the rat spinal cord dorsal horn. J. Neurosci. 20, 4922-4929. 